\title{
Perceptions of Students from the Department of Computer Education and Instructional Technologies Regarding the Concept of Curriculum
}

\author{
Melis Yeşilpınar Uyar $^{1}$ \\ ${ }^{1}$ Educational Sciences, Çukurova University, Adana, Turkey \\ Correspondence: Melis Yeşilpınar Uyar, Faculty of Education, Çukurova University, Adana, TR-01330, Turkey. \\ Tel: 322-338-6733. E-mail: myesilpinar@cu.edu.tr
}

Received: April 14, 2017

doi:10.5539/ies.v10n9p9

\author{
Accepted: May 15, 2017 Online Published: August 27, 2017 \\ URL: https://doi.org/10.5539/ies.v10n9p9
}

\begin{abstract}
In the study, the purpose was to determine the perceptions of students from the department of Computer Education and Instructional Technologies regarding the concept of curriculum. The participants of the study conducted with the phenomenology research design were 212 preservice teachers. The research data were collected via document analysis and interviews. For the analysis of the data, the inductive content analysis method was used. The results revealed that the preservice teachers perceived the concept of curriculum as a process with positive and negative features which emphasize change and development. The results also demonstrated that the participants perceived their levels of knowledge about curriculum as partly sufficient. In addition, it was found that undergraduate education has an important role in the development of these perceptions. Moreover, the results emphasized the need for making more planned and systematic regulations in relation to the functioning of curriculum studies in Turkey. Lastly, the results demonstrated that there is a need for regulations in the structure of the preservice teacher education curricula to give meaning to the concept of curriculum.
\end{abstract}

Keywords: computer education and instructional technologies, curriculum, phenomenology, teacher education

\section{Introduction}

Today, it is seen that the knowledge, skills and values that a learner is expected to have changed in line with the social, scientific and economic developments. Curricula, which act as a tool for the training of individuals, have an important role in this process. It is pointed out that the concept of curriculum, which is widely used, has various definitions and changes depending on the viewpoints of researchers and practitioners (Skilbeck, 1984).

For instance, Tyler (2014) regards curriculum as a tool to achieve educational goals, while D. Tanner and L. Tanner (2007) explains it as a process which helps restructure the current knowledge and experiences as the basis of their future knowledge and experiences. In addition, there are several other definitions of curriculum such as planned learning experiences (Saylor, Alexander \& Lewis, 1981) and organized learning outcomes (Posner \& Rudnitsky, 2006).

It is pointed out that these differences in the perceptions and definitions of curriculum are due to the viewpoints regarding knowledge, education and implementation and that not only the goals, functions and context of curriculum but also the strategies used in the process result in the differences in viewpoints (Oliva, 2005; Skilbeck, 1984; D. Tanner \& L. Tanner, 2007; Tyler, 2014). In addition, it is seen that all the definitions include one or more of such elements of curriculum as goals, content and the process of learning-teaching and measurement-evaluation. The meaning conveyed by the importance and place of these elements in the curriculum is thought to be another factor that leads to the differences in the definitions (D. Tanner \& L. Tanner, 2007).

Planning of the curriculum development process is based on the interaction between these four basic elements of curriculum (Demirel, 2007; Oliva, 2005). In this process, goals have influence on other elements of curriculum such as selection and organization of content and the processes of learning-teaching and evaluation (Brandt \& Tyler, 2007; Tenbrink, 2011), and the relational process involving these elements is shaped within the framework of factors related to the society, individuals and knowledge (Tyler, 2014). Successful implementation of the planned design by reflecting it to the school and class levels requires teachers' understanding, skills and 
knowledge about the goals, target population, planning, implementation and evaluation of the curriculum as well as about the roles of the participants (Brandt \& Tyler, 2007; Lewy, 1991; Li, 2006; Maphosa \& Mutopa, 2012; Ornstein \& Hunkins, 1998; Tutkun, 2010). Accordingly, it is obvious that it is necessary to develop teachers and preservice teachers' skills and knowledge about curriculum and about the curriculum development process via pre-service and in-service teacher education.

Besides teachers' knowledge and skills regarding curriculum, their curriculum fidelity as well as their beliefs, attitudes and perceptions regarding curriculum are also reported to be among the factors influential on effective implementation of curriculum (Bartiromo \& Etkina, 2009; Bezzina, 1991; Handal \& Herrington, 2003; Pietarinen, Pyhältö, \& Soini, 2016; Yıldırım \& Kasapoğlu, 2015). Perceptions, which are quite important in the fields of science and philosophy, constitute the main way of individuals' cognitive communication with their environment, and all conceptual knowledge develops based on this awareness (Efron, 1969). Perceptions, which allow individuals to take action regarding a phenomenon, an event or a situation, are thought to have direct or indirect effects on teachers' participation in the curriculum development process (Bezzina, 1991). For this reason, for effective implementation of curricula, first, it is necessary to determine and examine the curriculum-related perceptions of teachers who have an active role in the process and especially those of preservice teachers who will undertake this responsibility in their future professional lives.

It is seen in studies in related literature that perceptions of faculty members, preservice teachers and teachers from different fields and education levels were determined via interviews, questionnaires (Alwan, 2006; Fraser \& Bosanquet, 2006; İşler, 2008; Mellegård, \& Pettersen, 2016; Park, \& Sung, 2013; Yanık, 2008; Yıldırım \& Kasapoğlu, 2015;Yurdakul, 2015) and metaphors (Anglin \& Dugan, 1982; Aykaç \& Çelik, 2014; Gültekin, 2013; Örten \& Erginer, 2016; Özdemir, 2012; Tobin \& Lamaster, 1995; Wahyudi, 2007). In addition, studies focusing on preservice teacher education were mostly conducted with students from the departments of Elementary School Teaching, Science Teaching, Social Sciences Teaching and Turkish Language Teaching. The present study was conducted with students from the department of Computer Education and Instructional Technologies, which generally covers the concepts of program and programming in related courses. In the study, the preservice teachers' perceptions regarding the concept of curriculum were determined via metaphors and examined profoundly via interviews.

Therefore, this study aimed to determine the perceptions of students from the department of Computer Education and Instructional Technologies regarding the concept of "curriculum". In line with this purpose, the following research questions were directed in the study:

- What are the categories under which preservice teachers group the curriculum-related metaphors in terms of common features of these metaphors?

- How do preservice teachers conceptualize curriculum?

- What are preservice teachers' views about the importance of curriculum?

- What are preservice teachers' perceptions of their self-efficacy regarding their knowledge about curriculum?

\section{Methods}

\subsection{Research Model}

The study was conducted using the phenomenology research design. In phenomenology studies, the phenomenon constituting the focus point could be a certain concept, experience, perception or a situation (Creswell, 2008; Johnson \& Christensen, 2004; Merriam, 2002; Yıldırım \& Şimşek, 2008). Therefore, in phenomenological studies it should be methodologically described how people experience and perceive some phenomenon (Patton, 2002). In the present study, the main phenomenon was determined as preservice teachers' perceptions regarding curriculum, and these perceptions were examined by related documents and interviews.

\subsection{Participants}

In the first phase of the study, the research data were collected through metaphors from the participants determined with the maximum variation sampling method. This strategy aims to describe the central themes that emerge from great variation (Patton, 2002). As the source of maximum variance, "success ranking of education faculties" were taken as basis. While determining this ranking, the data provided by "University Ranking by Academic Performance (URAP)" at the time of determining the participants of the present study were used. In this ranking, among 103 state universities, two universities ranked in the top-10 list of universities and two other universities listed among the first and last 50 universities were included in the study. Accordingly, a total of 212 
$2^{\text {nd }}$ grade, $3^{\text {rd }}$ grade and $4^{\text {th }}$ grade preservice teachers attending the department of Computer Education and Instructional Technologies from four different universities participated in the study. In the second phase of the study, interviews were held with six volunteering preservice teachers determined with the convenience sampling method (Patton, 2002). Table 1 presents personal information about the participants.

Table 1. Personal information about the participants

\begin{tabular}{|c|c|c|c|c|c|}
\hline \multirow{2}{*}{ Phases } & \multicolumn{4}{|l|}{ Document Analysis } & \multirow{2}{*}{$\begin{array}{l}\text { Interview } \\
\text { Participants } \\
\end{array}$} \\
\hline & Participants & & $\mathbf{f}$ & $\%$ & \\
\hline \multirow{11}{*}{ Personal Information } & \multirow{4}{*}{ University } & $\mathrm{A}$ & 63 & 30 & G1, G2, G3, G4, G5, G6 \\
\hline & & $\mathrm{B}$ & 71 & 33 & - \\
\hline & & $\mathrm{C}$ & 37 & 17 & - \\
\hline & & $\mathrm{D}$ & 41 & 20 & - \\
\hline & \multirow{2}{*}{ Gender } & Female & 92 & 43 & G1, G2, G3, G4, G5, \\
\hline & & Male & 103 & 49 & G6 \\
\hline & \multirow{3}{*}{ Class Grade } & 2 & 67 & 32 & G2,G3, G5 \\
\hline & & 3 & 100 & 47 & G1,G4, G6 \\
\hline & & 4 & 45 & 21 & - \\
\hline & \multirow{2}{*}{ General Academic Average } & $1.80-2.85$ & 115 & 54 & G5 \\
\hline & & 2.86 and higher & 97 & 46 & $\mathrm{G} 1, \mathrm{G} 2, \mathrm{G} 3, \mathrm{G} 4, \mathrm{G} 6$ \\
\hline
\end{tabular}

As can be seen in Table 1, the number of the female students was close to that of the male students, and 17 participants did not mark their gender. More than half of the participants were students at the universities of A and $\mathrm{B}$, and their general academic averages ranged between 1.80 and 2.85 . With respect to their class grades, there were more students in the $3^{\text {rd }}$ class grade than in other class grades.

Among all the students interviewed, five of them were female, and one of them was male. In addition, all of them were $2^{\text {nd }}$ or $3^{\text {rd }}$ grade students attending the University of A. Also, almost all the students had a general academic average of 2.86 or higher. Moreover, all the participants reported that they took a course with a content covering curriculum or curriculum development process during their undergraduate education.

\subsection{Data Collection}

In order to collect data in the study, the methods of document analysis and interview were applied. Within the scope of document analysis, an open-ended form was used to obtain personal information about the preservice teachers and to determine their perceptions regarding the concept of curriculum via metaphors. The purpose of using metaphors, which constitute the basis of theories and models, is to interpret an unknown educational phenomenon with the help of a known event or known events (Botha, 2009). In this respect, first, the preservice teachers were briefly informed about metaphors and then asked to mark the personal information about them and to complete the sentence of "curriculum is like ... because ..." given in the data collection tool.

For the interviews, a semi-structured interview form developed by the researcher was used. The first part of the data collection tool included questions directed to obtain personal information about the students and to determine whether they had taken any course related to curriculum and how they perceived their levels of knowledge about the concept of curriculum. Following this, the students were asked to respond to questions regarding their conceptualization of curriculum, their rationale for the metaphors they produced, the factors which were inefficient or which developed their levels of knowledge about curriculum, the importance of curriculum for the education system and for the curriculum development process, and contribution of their knowledge about curriculum to their profession.

\subsection{Data Analysis}

For the analysis of the data, the inductive content analysis method was used (Patton, 2002). As for the analysis of the metaphors produced by the students, the phases followed by Saban (2008) were taken into account. In this process, first, the metaphors produced were named and put in alphabetic order. Following this, the data collected from 48 participants who did not provide any rationale, who did not produce any valid metaphor, who failed to make an association with the metaphor used and who explained their rational for the metaphors considering the school and education rather than the curriculum were excluded. Next, a total of 212 metaphors produced were identified, and the categories explaining these metaphors were formed. For the analysis of the interview data, 
first, the categories related to conceptualization of curriculum, perception of self-efficacy regarding their knowledge level, reasons for efficacy perception, and importance of the efficacy level were determined. Following this, the models revealing the relationships between the categories were formed. In this process, a computer-aided qualitative data analysis software was used.

Within the scope of validity and reliability studies, initially, for content validity, four faculty members who were experts in the field of curriculum and instruction and who previously conducted studies on metaphors as well as studies using the phenomenology design were asked for their views about the interview form prepared. In line with the experts' views, the personal information questions were revised, and the necessary changes and corrections were done. In addition, considering other suggested strategies (Brantlinger, Jimenez, Klingner, Pugach \& Richardson, 2005; Creswell, 2008; Guba, 1981; Patton, 2002), the research questions, the related design and the findings obtained were presented to a field expert for his/her views. In addition, multiple methods were applied using the interview and document analysis techniques together, and a verification study was conducted. Also, direct quotations were used as a support while explaining the categories, and these quotations obtained from the open-ended form included the numbers coded for each form, the participants' gender, their universities and their class grades. Lastly, while presenting the quotations obtained via the interviews, codes representing the participants such as G1 and G2 were used accompanied by the page numbers in the raw data texts.

\section{Results}

\subsection{Categories Explaining the Metaphors Regarding the Concept of Curriculum}

As can be seen in Figure 1 below, the metaphors produced by the preservice teachers in relation to the concept of curriculum were found to belong to seven categories.

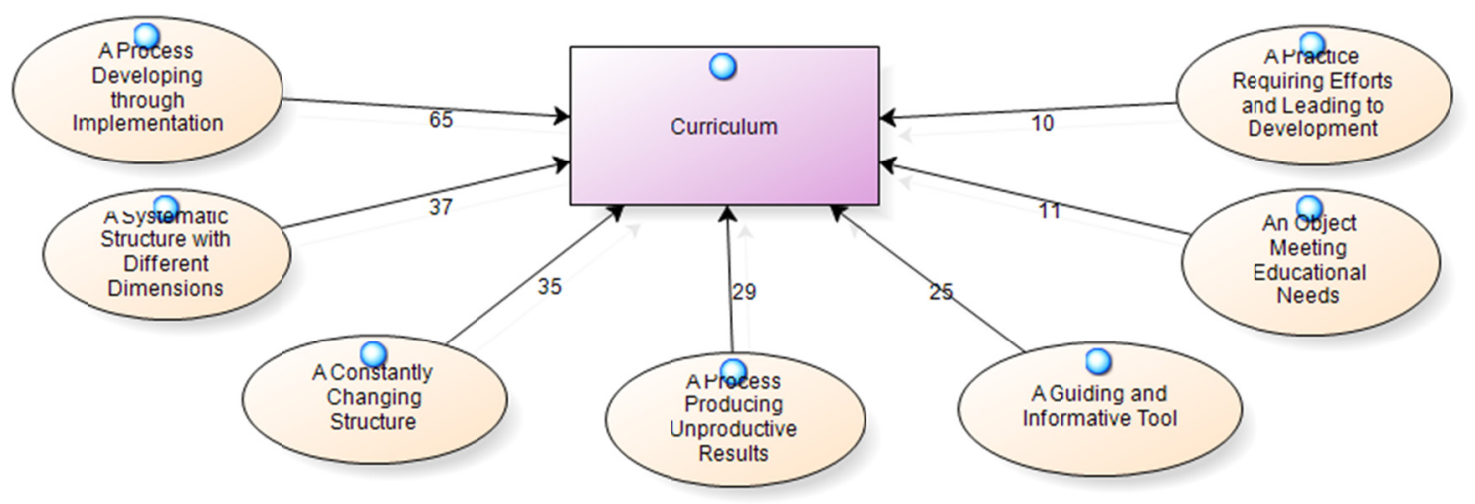

Figure 1. Categories explaining the metaphors regarding the concept of curriculum

When the categories presented in Figure 1 are examined, it is seen that 65 participants perceived curriculum as a "Process Developing through Implementation". It is also seen that the other metaphors produced regarding curriculum belonged to the categories of "A Systematic Structure with Different Dimensions, A Constantly Changing Structure, A Process Producing Unproductive Results, A Guiding and Informative Tool, An Object Meeting Educational Needs, A Practice Requiring Efforts and Leading to Development". The metaphors found in the categories have been explained under related sub-headings.

3.1.1 A Process Developing through Implementation

The metaphors under this category and the related frequencies can be seen in Table 2. 
Table 2. Metaphors belonging to the category of a process developing through implementation

\begin{tabular}{|c|c|c|c|c|c|}
\hline Metaphors & f & Metaphors & $\mathbf{f}$ & Metaphors & $\mathbf{f}$ \\
\hline Tree & 10 & Flower & 1 & Court of Justice & 1 \\
\hline Car & 2 & Beating & 1 & Machine & 1 \\
\hline White & 2 & Notebook & 1 & Fruit Tree & 1 \\
\hline Dough & 2 & Sea & 1 & Banana & 1 \\
\hline Agriculture & 2 & Diet & 1 & Music & 1 \\
\hline Seed & 2 & Wardrobe & 1 & Ungrateful Cat & 1 \\
\hline Young Tree & 1 & Film & 1 & Orchid & 1 \\
\hline Key Words & 1 & Ship & 1 & Php software & 1 \\
\hline Love & 1 & Movement of the Sun and the Earth & 1 & Colors on Palette & 1 \\
\hline Mirror & 1 & Empty Bag & 1 & Programming Language & 1 \\
\hline Bank & 1 & Empty Picture Frame & 1 & Bird & 1 \\
\hline Baby & 1 & Medicine & 1 & Wood Block & 1 \\
\hline Brain & 1 & Construction & 1 & Elastic Band & 1 \\
\hline Computer & 1 & Internet & 1 & Color & 1 \\
\hline Computer Software & 1 & Paper & 1 & Water & 1 \\
\hline Growing a plant & 1 & Cat & 1 & Soil & 1 \\
\hline Plant & 1 & Keyboard & 1 & A house newly moved into & 1 \\
\hline \multicolumn{4}{|c|}{ Number of Metaphors } & \multicolumn{2}{|l|}{52} \\
\hline & & & $\mathbf{F}$ & \multicolumn{2}{|l|}{65} \\
\hline
\end{tabular}

When Table 2 is examined, it is seen that 52 metaphors were produced under the category of a process developing through implementation and that the metaphors of "tree, car, white, seed, dough and agriculture" were reported by more than one participant. One of the participants producing the metaphor of tree stated the related rationale as follows:

Curriculum is like a tree because let's take the tree as an example, it is a young tree at the beginning. If you water it, it grows up in time. When you get knowledge by doing research in relation to the curriculum, you open up your horizon via brainstorming. Thus, people develop themselves just like the grow-up of a tree (S8, Female, 4, University A).

Another student produced the metaphor of agriculture under this category. The student reported the related rationale as follows:

I resemble the curriculum to agriculture because you first plant the seed, then you meet that's needs: I mean you water it in line with its needs, and you think about the future. That's, it meets the human's needs. Thus, you develop your creativity. I mean you do what should do (G3, Interview, p. 2).

3.1.2 A Systematic Structure with Different Dimensions

Table 3 presents the metaphors produced under this category and the related frequencies.

Table 3. Metaphors belonging to the category of a systematic structure with different dimensions

\begin{tabular}{l|l|l|l|l|l}
\hline Metaphors & F & Metaphors & f & Metaphors & f \\
\hline Tree & 6 & Sentence & 1 & Table & 1 \\
\hline Rainbow & 4 & Plane Tree & 1 & Blue & 1 \\
\hline Machine & 2 & Diet Program & 1 & School & 1 \\
\hline Ocean & 2 & Apple & 1 & Leek & 1 \\
\hline Family & 1 & Factory & 1 & Puzzle & 1 \\
\hline Military Army & 1 & Ship & 1 & Salad & 1 \\
\hline Nitrogen Cycle & 1 & Grey-Black & 1 & Air & 1 \\
\hline White & 1 & Human & 1 & Responsibility & 1 \\
\hline Hardware in Computer Case & 1 & Book Number of Metaphors & 27 & 1 \\
\hline
\end{tabular}


When Table 3 is examined, it is seen that 27 metaphors were produced under the category of a systematic structure with different dimensions and that the metaphors of "tree, rainbow, machine and ocean" were reported by more than one participant. One of the participants producing the metaphor of rainbow reported the related rationale as follows:

Curriculum is like a rainbow because it has all colors. All of them including the teacher, the curriculum and the materials have different tastes. There are all kinds of colors, students, teachers and teaching styles. Just like a rainbow, it involves everything (S92, Female, 3, University B).

Another participant produced the metaphor of factory under this category. While explaining the reason for using this metaphor, the participant emphasized the systematic structure of curriculum saying:

There is a system; I mean education has a certain system. A factory has a similar system, and it functions based on a certain system when we consider a factor in a general respect. For example, I resembled the teacher to a machine used in a factor and the student to a raw material. I mean students are like input products. The products manufactured are like the outcomes a student has achieved. I made this association because I thought a factor has a system like this (G2, Interview, p. 2).

\subsubsection{A Constantly Changing Structure}

Table 4 demonstrates that metaphors produced under this category and the related frequencies.

Table 4. Metaphors belonging to the category of a constantly changing structure

\begin{tabular}{l|l|l|l|l|l}
\hline Metaphors & f & Metaphors & f & Metaphors & f \\
\hline Chameleon & 3 & Household Needs & 1 & Play Dough & 1 \\
\hline Alive & 2 & Evolution & 1 & Toy & 1 \\
\hline Telephone & 2 & Joke & 1 & Pie & 1 \\
\hline Technology & 2 & Rainbow & 1 & Eraser & 1 \\
\hline Aimless Person & 1 & Weather Condition & 1 & Politics & 1 \\
\hline Lift & 1 & The Political Party in Power & 1 & A Constantly Changing Cycle & 1 \\
\hline Basketball Team & 1 & People & 1 & A Building without a Foundation & 1 \\
\hline Brain & 1 & Woman & 1 & $\begin{array}{l}\text { Most Fashionable and Favored Dress } \\
\text { in 2016 }\end{array}$ & 1 \\
\hline Flower & 1 & Red & 1 & Virus Scan Software & 1 \\
\hline $\begin{array}{l}\text { A House Constructed without } \\
\text { Use of Any Iron }\end{array}$ & 1 & Season & 1 & & \\
\hline
\end{tabular}

When Table 4 is examined, it is seen that a total of 30 metaphors were produced under the category of a constantly changing structure and that the metaphors of "chameleon, alive, telephone and technology" were reported by more than one participant. One of the participants producing the metaphor of chameleon reported the related rationale as follows:

Chameleon constantly changes it color, and the curriculum always changes as well (S92, Female, 2, University A).

Another participant resembled the curriculum to a house constructed without use of any iron saying the related rationale as follows:

Think that you are building a house, and you just use cement and no iron for the columns. That house will undoubtedly collapse soon. You will build another house, and then another. All these houses will collapse again as they do not have any infrastructure or foundation... Curriculum is just like this because if a curriculum does not have a strong substructure and you constantly add something to it, then you always feel that it will collapse one day (G4, Interview, p.3).

\subsubsection{A Process Producing Unproductive Results}

Table 5 presents the metaphors produced under this category and the related frequencies. 
Table 5. Metaphors belonging to the category of a process producing unproductive results

\begin{tabular}{l|c|l|c}
\hline Metaphors & f & Metaphors & f \\
\hline River & 1 & Turtle & 1 \\
\hline Use of a car engine on a bicycle & 1 & Creamy Crumpet with Thick Syrup & 1 \\
\hline Argentina National Football Team & 1 & Book & 1 \\
\hline Horse Race & 1 & Clamp & 1 \\
\hline Horse Trainer & 1 & Passenger Standing on a Bus & 1 \\
\hline A Chair with a Broken Leg & 1 & Dead Whale & 1 \\
\hline Iceberg & 1 & Platonic Love & 1 \\
\hline Seeds & 1 & Cigarette & 1 \\
\hline Trash & 1 & A Dark Room & 1 \\
\hline Trial-and-Error Board & 1 & God & 1 \\
\hline Dinosaur & 1 & Meal with an Unknown Recipe & 1 \\
\hline Man & 1 & High-Heel Shoes & 1 \\
\hline A computer without a Harddisc & 1 & Old Tree & 1 \\
\hline A Smart Phone without the Internet & 1 & Escalator & 1 \\
\hline Factory & 1 & & \\
\hline & Number of Metaphors & 29 & \\
\hline & F & 29 &
\end{tabular}

When Table 5 is examined, it is seen that 29 metaphors were produced under the category of a process producing unproductive results. Two of the participants were found to produce the metaphors of iceberg and factory under this category. The students reported their views in relation to a process producing unproductive results, saying:

Here the purpose is to place students in line with the goals of the education system rather than according to their qualifications. Therefore, I resembled it to a factory because in factory a raw material is processed by machines and transformed into a certain product. I mean students are just like the raw materials, and the machines are teachers, who train these students based on certain standards (G1, Interview, p. 2).

I actually resembled curriculum to an iceberg. I mean the curriculum is just the tip of the iceberg. Teaching is superficial, and it is mostly based on memorization. In fact, teachers should provide more in-depth instruction. That's, there should be less memorization and more practice (G6, Interview, p. 1).

\subsubsection{A Guiding and Informative Tool}

Table 6 presents the metaphors produced under this category and the related frequencies.

Table 6. Metaphors belonging to the category of a guiding and informative tool

\begin{tabular}{l|c|l|c|l|c}
\hline Metaphors & f & Metaphors & f & Metaphors & f \\
\hline Sun & 2 & Real Estate Agent & 1 & Microcontroller & 1 \\
\hline Network System & 1 & E-Trade & 1 & Microprocessor & 1 \\
\hline Tree & 1 & Football League Table & 1 & Conductor & 1 \\
\hline Arms of Octopus & 1 & Sunny Day & 1 & Teacher & 1 \\
\hline Mother's Compassion & 1 & Map & 1 & Overhead Projector & 1 \\
\hline Glowworm & 1 & Cow & 1 & Public Transportation & 1 \\
\hline Father & 1 & Operating System & 1 & Living & 1 \\
\hline Government & 1 & Self-Development and Self-Training & 1 & Travelling & 1 \\
\hline \multicolumn{7}{r}{ Number of Metaphors } & 24 \\
\hline \multicolumn{7}{r}{ F } & 25 \\
\hline
\end{tabular}

When Table 6 is examined, it is seen that 24 metaphors were produced under the category of a guiding and informative tool and that the metaphor of sun was produced by more than one participant. One of the participants producing the metaphor of sun reported the related rationale as follows:

Curriculum is like the sun because it should be enlightening. It should give knowledge to students, and it is important to transfer the correct knowledge to young brains because illiteracy can only be overcome with 
correct enligthment (S120, Female, 4, University B).

\subsubsection{An Object Meeting Educational Needs}

It was found that 11 metaphors were produced under this category. These metaphors were the sun, the mainboard of a computer, a feeling, the drummer of a music group, human, the organism system, the skeleton system, a hungry baby, lego, water and green. One student emphasizing the educational needs by using the metaphor of water said:

It is quite important in terms of learning. I resembled the curriculum to water, which is the most important for human life. People cannot live without water, and a curriculum is a must in learning and teaching (S50, Female, 2, University A).

\subsubsection{A Practice Requiring Effort and Leading to Development}

Under this category, a total of 10 metaphors were produced. These metaphors were axe, unity, candy apple, weight-lifting, human, pencil sharpener, heavy metal, thoroughbred horse, illusion and jigsaw. One of the students producing the metaphor of jigsaw reported the related rationale as follows:

Initially, you get very bored, but when you start doing something, you develop your horizon. I mean you start to understand its value (S39, Female, 2, University A).

\subsection{Views about the Importance, Conceptualization and Self Efficacy Perception of Curriculum}

In the process of examining the participants' perceptions of curriculum via the interviews, the preservice teachers' conceptualization of curriculum was determined. The process also revealed the participants' views about the importance of curriculum as well as their perceptions of self-efficacy regarding the concept of curriculum. Figure 2 presents the categories and the sub-categories determined in line with their views.

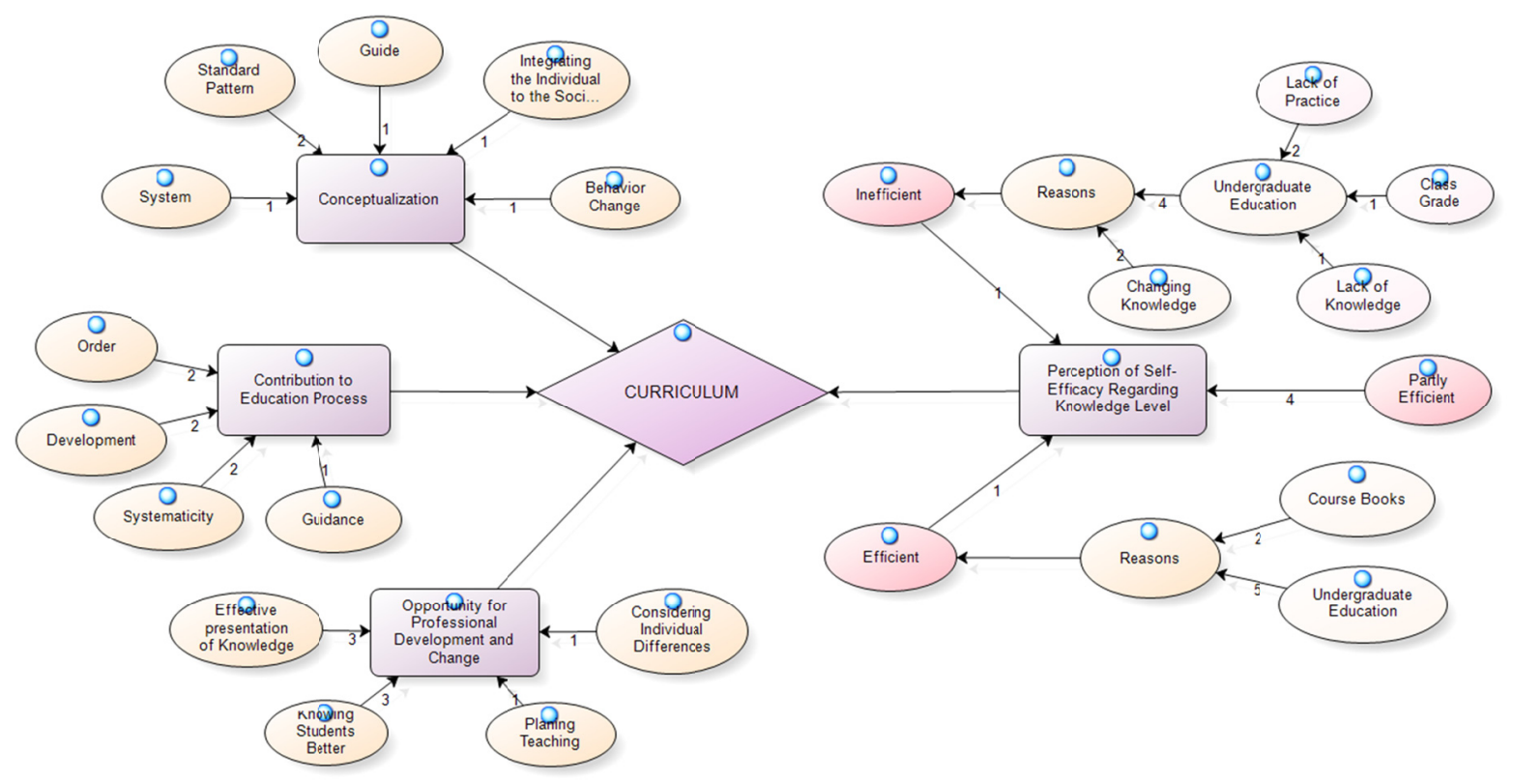

Figure 2. Views about the importance, conceptualization and self efficacy perception of curriculum

When Figure 2 is examined, it is seen that the participants conceptualized curriculum as a standard pattern, system, guide, behavior change and as the process of integrating the individual to the society. The participants also reported that curriculum regulates and systematize the education process, acts as a guide to this process and contributes to its development. One of the participants conceptualized curriculum as a standard pattern and reported views about the systematicity of the education process saying:

It develops in a certain standard pattern. I mean it tries to force students to meet that standard rather than focusing on personal qualities of students. It really has unchangeable boundaries... if you want to develop a curriculum, then you will have to establish the building block of education and then try to achieve the goals 
accordingly. Just as you plan the introduction, the development and the result while organizing a process, I think you are supposed to consider these phases in education as well (G1, Interview, p. 2-3).

It was found that another category explaining the perceptions regarding curriculum was the opportunity for professional change and development. Under this category, the participants stated that they would make effective presentation of knowledge, know students better, plan the teaching process and take individual differences intro consideration if they became knowledgeable about the concept of curriculum. Under this category, one of the participants mentioning effective presentation of knowledge said:

Let's suppose we do not have any knowledge about curriculum and we are teachers without applying any system. Then, we will not be able to provide our students with systematic knowledge, and I think we will not teach them in an organized manner, either. Thus, I believe planned education is important (G5, Interview, p.3).

When the participants' perceptions regarding the level of knowledge about the concept of curriculum were examined, it was seen that four of the participants found themselves partly efficient in relation to this and that one participant considered himself or herself to be inefficient. In addition, one participant perceived himself or herself to be efficient regarding this. The participants mentioned course books and undergraduate education in relation to the reasons for efficacy. When the reasons for inefficacy were examined, it was seen that the participants based their inefficacy on their changing knowledge and associated it with their undergraduate education. In this respect, the participants reported that the knowledge provided during undergraduate education, lack of practice and class grades all caused them to perceive themselves to be inefficient.

One of the participant who found himself or herself partly efficient regarding his or her level of knowledge about the concept of curriculum stated that he or she should develop himself or herself due to constantly changing knowledge and mentioned the positive influence of his or her undergraduate education on his or her current knowledge, saying:

I would say it is partly efficient... We are in a constantly changing era. Everything is changing including students and teachers. Thus, the curriculum cannot remain unchanged. It should always develop. Therefore, there is a need for constant related studies... For example, most of our instructors at university teach this in detail. In this way, we really learn at micro level via practice by focusing on all related details and preparing curricula (G6, Interview, $p .1-3$ ).

Another participant stated that he or she perceived himself or herself to be inefficient and associated this with the insufficient knowledge provided during their undergraduate education. It was also found that the participant conceptualized curriculum as a behavior change. In this respect, it was seen that the participant's level of knowledge about curriculum was not sufficient and that he or she had a realistic perception of self-efficacy:

To me, curriculum actually leaves a permanent trace. Thus, it leads to a permanent behavior change... For me, it is not efficient. I believe the education I have taken is not sufficient... well, I feel I need to know more because I learned more when I was a high school student. I thought I would have learned more here (G3, Interview, $p$. 2-3).

\section{Discussion, Conclusion and Implications}

When the findings obtained in the study were examined with respect to the metaphors produced by the participants, it was seen that positive emphasis was made on curriculum in relation to the categories of "a process developing through implementation, a systematic structure with different dimensions, a guiding and informative tool, an object meeting educational needs and a practice requiring effort and leading to development» and that negative emphasis was made regarding the categories of "a constantly changing structure and a process producing unproductive results". Similar to the results obtained in the present study, it is reported in related literature that the participants of other studies examining the perceptions regarding curriculum with the help of metaphors produced metaphors reflective their positive perceptions (Gültekin, 2013; Özdemir, 2012) and negative perceptions (Aykaç \& Çelik, 2014). In addition, the findings obtained via the interviews in this study demonstrated that two participants producing the metaphors of factory and iceberg conceptualized curriculum as a standard pattern and that the participants emphasized a process producing unproductive results.

The findings revealed that the participants perceived curriculum to be a process which constantly changes and produces unproductive results. Among the reasons for this perception is that the curricula in Turkey continuously change without any effective planning, which leads to undesirable consequences. As a support to this, in other related studies, it was found that change-based structuring studies conducted regarding the structure and implementation of curricula lead to certain problems (Akpınar, Dönder, Yıldırım, \& Karahan, 2012; Handal \& 
Herrington, 2003; Kabapınar \& Karakurt, 2016; Millar, 2016; Muraraneza, Mtshali \& Mukamana, 2017; Öztürk, Yalvaç-Hastürk, \& Demir, 2013; Yurdakul, 2015). As mentioned by Memon (1997), a curriculum change is a complex process influenced by curriculum-based, instructional and organizational factors. For this reason, the process of change should be carried out on the basis of efficient sources and supports considering these three factors (cited in Handal \& Herrington, 2003).

When the metaphors produced by the participants were examined more in detail, it was seen that in relation to the categories emphasizing positive features, the curriculum is perceived to be a process which leads to development and which is open to development. As a support to this, in related studies reported in literature, it is seen that the curriculum was explained with the metaphors of a phenomenon open to development (Gültekin, 2013), improvement and development (Anglin \& Dugan, 1982) and that it was categorized as a guiding process or tool with the help of the metaphors produced (Özdemir, 2012; Yurdakul, 2015).

When the participants' perceptions regarding curriculum were evaluated with respect to the metaphors, it was seen that the participants with negative perceptions emphasized a change in curriculum and that they found this change inefficient for development. As for the participants with positive views, it was seen that they also perceived the changes in curriculum to be a development process.

In addition, the findings obtained via the interviews demonstrated that most of the participants perceived their levels of knowledge about curriculum to be partly efficient and that only one participant found his or her level of knowledge efficient. A striking finding is that some of the participants thought their undergraduate education contributed to their self-efficacy while others believed their undergraduate education caused them to feel themselves inefficient

When the metaphors produced by the participants were examined, it was seen that there was such metaphors as "computer, keyboard, php software, hardware, technology, virus scan software, computer without a harddisc, microcontroller, microprocessor and mainboard of a computer". In this respect, it could be stated that the field-related courses taken by the participants during their undergraduate education directed their perceptions regarding curriculum. The reason is that other studies examining the metaphorical perceptions of preservice teachers from different departments did not reveal any similar metaphors except for the metaphor of computer (Aykaç \& Çelik, 2014; Gültekin, 2013). In addition, while mentioning the related rationales, the preservice teachers made associations with curriculum. Moreover, they did not confuse it with such concepts as "program" and "programming", which are frequently used in field courses. However, although almost all the participants had taken a course with a content covering curriculum and curriculum development, they reported that their levels of knowledge were not efficient at all.

The fact that the participants did not perceive their levels of knowledge about curriculum to be inefficient could be said to demonstrate that the participants' knowledge about curriculum was not meaningful or permanent though they were provided with the related knowledge within the scope of such courses as "Introduction to Educational Sciences, Instructional Design, Modern Learning Theories, Teaching Principles and Methods, and Curriculum Development in Education. Another point supporting this view is that the data collected from 48 participants who considered the school and education itself rather than the curriculum while reporting their rationales for the metaphors were not included in the study. In addition, the interviews held with the participants also revealed that one of them conceptualized curriculum as a behavior change and perceived his or her level of related knowledge to be inefficient. Furthermore, the participants mentioned the positive contribution of undergraduate education but stated that lack of practice in courses was a factor negatively influential on the perception of efficacy.

The results of a study conducted by Yıldırım and Kasapoğlu (2015) demonstrated that there is a strong relationship between teachers' perceptions regarding the implementation of learning-teaching activities and their perceptions regarding curriculum change. It is also reported that in-service training processes are among the factors constituting the basis of curriculum-related perceptions (Demir \& Şahin, 2009; Yıldırım \& Kasapoğlu, 2015). This situation shows the importance of preservice teacher education curriculum for the development of self-efficacy perception regarding curriculum.

In the light of all the points mentioned above, it could be stated that the content provided for the participants in relation to curriculum within the scope of the related field courses does not contribute much to the development of the participants' conceptual knowledge at all. Moreover, it is thought that there is a need for restructuring the contents of the related field courses as well as for the integration of courses into practice. In studies in related literature supporting this view, it is pointed out that the theory-based courses related to the teaching profession should involve practical studies as well (Çalışkan, 2014; Dinçer, 2016; Kumral, 2010; Kurt \& Ekici, 2013; 
Mehdinezhad, 2008; Molina, Fernandez \& Nisbet, 2013; Öztürk, 2012; Ralph, 2014; Ruys, Van Keer \& Aelterman, 2010; Yeşilpınar-Uyar, 2016).

In addition, the participants reported that curriculum regulates, systematizes and guides the education process and contributes to the development of the process and that it provides opportunities for professional development and change. In this respect, similar to the results obtained in a study conducted by Gültekin (2013), it could be stated that the preservice teachers participating in the present study were aware of the contribution of curriculum to the education process and of its importance for professional development.

Consequently, in the study, it was found that the students attending the department of Computer Education and Instructional Technologies perceived the concept of curriculum as a process which emphasizes change and development and which involves positive and negative features. It was also revealed that the participants perceived their levels of knowledge about curriculum to be partly efficient, and it was concluded that undergraduate education had an important role in the development of these perceptions.

All these results were limited to the data collected from preservice teachers attending the department of Computer Education and Instructional Technologies from different state universities and demonstrate that more planned and systematic regulations are necessary to meet the needs determined within the scope of curriculum development studies conducted in Turkey. In addition, it is thought that teacher education courses should be supported with practical studies for students to give meaning to the concept of curriculum. Also, in future studies, researcher could investigate the problems leading to negative perceptions regarding curriculum and conduct studies to overcome these problems.

\section{References}

Akpınar, B., Dönder, A., Yıldırım, B., \& Karahan, O. (2012). The evaluation of $4+4+4$ system (model) in education in the context of opposite curriculum. Marmara University Atatürk Education Faculty Journal of Educational Sciences, 36(36), 25-39.

Alwan, F. H. (2006). An analysis of English language teachers' perceptions of curriculum change in the United Arab Emirates (Unpublished doctoral dissertation). The University of Exeter, Exeter, UK.

Anglin, L. W., \& Dugan, T. (1982, March). Teachers' perceptions of existing and ideal school curriculum: An analysis of metaphors. Paper presented at the Annual Meeting of the American Educational Research Association, New York, USA. Retrieved from https://eric.ed.gov/?id=ED217037

Aykaç, N., \& Çelik, Ö. (2014). Comparison of methaphoric perception of teachers and pre-service teachers about curriculum. Education and Science, 39(173), 328-340.

Bartiromo, T., \& Etkina, E. (2009, November). Implementing reform: Teachers' beliefs about students and the curriculum. In M. Sabella, C. Henderson, \& C. Singh (Eds.), AIP Conference Proceedings (Vol. 1179, No. 1, pp. 89-92). AIP. https://doi.org/10.1063/1.3266762

Bezzina, M. (1991, July). Being free and feeling free: primary teachers' perceptions of participation in curriculum development. Paper presented at the Annual Conference of the Australian Curriculum Studies Association, Adelaide, South Australia. Abstract retrieved from http://files.eric.ed.gov/fulltext/ED368693.pdf.

Botha, E. (2009). Why metaphor matters in education. South African Journal of Education, 28, 431-444.

Brandt, R. S., \& Tyler, R. W. (2007). Goals and objectives. In A.C. Ornstein, E. F. Pajak, \& S. B. Ornstein (Eds.), Contemporary issues in curriculum (4th ed., pp. 12-21). Pearson/Allyn and Bacon.

Brantlinger, E., Jimenez, R., Klingner, J., Pugach, M., \& Richardson, V. (2005). Qualitative studies in special education. Exceptional Children, 71(2), 195-207. https://doi.org/10.1177/001440290507100205

Çalışkan, İ. (2014). Identifying the needs of pre-service classroom teachers about science teaching methodology courses in terms of Parlett's Illuminative Program Evaluation Model. International Journal of Education in Mathematics, Science and Technology, 2(2), 138-148. https://doi.org/10.18404/ijemst.79527

Creswell, J. W. (2008). Educational research: planning, conducting and evaluating quantative and qualitative research (3nd ed.). Upper Saddle River, NJ: Pearson Education, Inc.

Demir, S., \& Şahin, S. (2009). The problems confronted by teachers related to the application of educational programmes formed according to constructivist approach in 1-5 grades primary schools. Journal of Qafqaz University, 26(1), 158-171.

Demirel, Ö. (2007). Eğitimde program geliştirme [Curriculum development in education] (10th ed.). Ankara: 
PegemaYayıncilik.

Dinçer, S. (2016). Assessing the computer literacy of university graduates. In Proceedings of the The Third International Conference on Open and Flexible Education (pp. 294-303). Hong Kong: Hong Kong Open University.

Efron, R. (1969). What is perception? In Proceedings of the Boston Colloquium for the Philosophy of Science 1966/1968 (pp. 137-173). Springer, Netherlands. https://doi.org/10.1007/978-94-010-3378-7_4

Fraser, S. P., \& Bosanquet, A. M. (2006). The curriculum? That's just a unit outline, isn't it? Studies in Higher Education, 31(3), 269-284. https://doi.org/10.1080/03075070600680521

Guba, E. G. (1981). Criteria for assessing the trustworthiness of naturalistic inquiries. ERIC/ECTJ Annual Review Paper, 29(2), 75-91.

Gültekin, M. (2013). The metaphors that primary education teacher candidates use regarding curriculum. Education and Sciences, 38(169). 126-141.

Handal, B., \& Herrington, A. (2003). Mathematics teachers' beliefs and curriculum reform. Mathematics education research journal, 15(1), 59-69. https://doi.org/10.1007/BF03217369

İşler, I. (2008). Teachers' perceived efficacy beliefs and perceptions regarding the implementation of the 2004 primary mathematics curriculum (Unpublished master's thesis). Middle East Technical University, Ankara, Turkey.

Johnson, B., \& Christensen, L. (2004). Educational research: quantitative, qualitative and mixed approaches (2nd ed.). Boston: Pearson Education Inc.

Kabapınar, Y., \& Karakurt, F. (2016). An evaluation of constructivist learning environments in social studies courses in Hakkari: Is the transition easy? Kastamonu University Kastamonu Education Journal, 24(4), 1897-1918.

Kumral, O. (2010). Faculty of education elementary school teacher's programme evaluation with educational criticism: A case study (Unpublished doctoral dissertation). Adnan Menderes University, Aydın, Turkey.

Kurt, H., \& Ekici, G. (2013). The effect of the educational planning and evaluation lesson on pre-service teachers' self-efficacy beliefs related to the teaching process. Elementary Education Online, 12(4), 1157-1172.

Lewis, S. A., Galen, J., Alexander, W. M., \& Lewis, A. J. (1981). Curriculum planning for better teaching and learning. New York: Holt, Rinehart and Winston.

Lewy, A. (1991). National and school-based curriculum development. Unesco: International Institute for Educational Planning.

Li, H. (2006). School-based curriculum development: An interview study of Chinese kindergartens. Early Childhood Education Journal, 33(4), 223-229. https://doi.org/10.1007/s10643-006-0061-7

Maphosa, C., \& Mutopa, S. (2012). Teachers' awareness of their role in planning and implementing school-based curriculum innovation. Anthropologist, 14(2), 99-106.

Mehdinezhad, V. (2008). Evaluation of teacher education programs by students and graduates (Unpublished doctoral dissertation). University of Turku, Turku, Finland.

Mellegård, I., \& Pettersen, K. D. (2016). Teachers' response to curriculum change: balancing external and internal change forces. Teacher Development, 20(2), 181-196. https://doi.org/10.1080/13664530.2016.1143871

Merriam, S. (2002). Assessing and evaluating qualitative research. In S. Merriam (Ed.), Qualitative research in practice: Examples for discussion and analysis (pp.18-36). San Francisco: Jossey-Bass.

Millar, V. (2016). Interdisciplinary curriculum reform in the changing university. Teaching in Higher Education, 21(4), 471-483. https://doi.org/10.1080/13562517.2016.1155549

Molina, R., Fernandez, M. L., \& Nisbet, L. (2013, April). Analyzing elementary preservice teachers' development of content and pedagogical content knowledge in mathematics through microteaching lesson study. Paper presented the Tenth Annual College of Education \& GSN Research Conference, Florida International University, Miami. Retrieved from http://digitalcommons.fiu.edu/cgi/viewcontent.cgi?article= $1181 \&$ context $=$ sferc 
Muraraneza, C., Mtshali, N. G., \& Mukamana, D. (2017). Issues and challenges of curriculum reform to competency-based curricula in Africa: A meta-synthesis. Nursing \& Health Sciences. https://doi.org/10.1111/nhs. 12316

Oliva, P. (2005). Developing the curriculum (6th ed.). Pearson Education, Inc.

Ornstein A. C., \& Hunkins F. P. (1998). Curriculum: foundations, principles, and issues (3rd ed.). Allyn \& Bacon, Needham Heights.

Örten, D., \& Erginer, E. (2016). Metaphorical perceptions on curriculum development made by the leading scholars in Turkey studying curriculum development. International Journal of Society Researches, 6(11), 387-414.

Özdemir, S. M. (2012). Metaphoric perceptions of prospective teachers regarding the concept of curriculum. Journal of Theoretical Educational Sciences, 5(3), 369-393.

Öztürk, İ. H. (2012). Wikipedia as a teaching tool for technological pedagogical content knowledge (TPCK) development in pre-service history teacher education. Educational Research and Review, 7(7), 182-191. https://doi.org/10.5897/ERR11.277.

Öztürk, N., Yalvaç-Hastürk, H. G., \& Demir, R. (2013). Teachers' opinions about the assessment and evaluation methods employed in elementary 4-5 th grades school science and technology teaching programs. Dicle University Journal of Ziya Gökalp Faculty of Education, 20, 25-36.

Park, M., \& Sung, Y. K. (2013). Teachers' perceptions of the recent curriculum reforms and their implementation: what can we learn from the case of Korean elementary teachers?. Asia Pacific Journal of Education, 33(1), 15-33. https://doi.org/10.1080/02188791.2012.756391

Patton, M. Q. (2002). Qualitative evaluation and research methods (3rd ed.). London: Sage Publications.

Pietarinen, J., Pyhältö, K., \& Soini, T. (2016). Large-scale curriculum reform in Finland-exploring the interrelation between implementation strategy, the function of the reform, and curriculum coherence. The Curriculum Journal, 1-19. https://doi.org/10.1080/09585176.2016.1179205

Posner, G. J., \& Rudnitsky, A. N. (2006). Course design: A guide to curriculum development for teachers (7th ed.). Pearson Education, Inc.

Ralph, E. G. (2014). The effectiveness of microteaching: Five years' findings. International Journal of Humanities Social Sciences and Education (IJHSSE), 1, 17-28.

Ruys, I., Van Keer, H., \& Aelterman, A. (2010). Collaborative learning in pre-service teacher education: an exploratory study on related conceptions, self-efficacy and implementation. Educational Studies, 36(5), 537-553. https://doi.org/10.1080/03055691003729021

Saban, A. (2008). Primary school teachers' and their students' mental images about the concept of knowledge. Elemantary Education Online, 7(2), 421-455.

Skilbeck, M. (1984) School-based curriculum development. London, Harper and Row.

Tanner, D., \& Tanner, L. N. (2007). Curriculum development: Theory into practice (4th ed.). New York: Macmillan.

Tenbrink, T. D. (2011). Instructional objectives. In J. M. Cooper (Ed.), Classroom teaching skills (pp. 21-44). Wadsworth, Cengage Learning.

Tobin, K., \& Lamaster, S. U. (1995). Relationships between metaphors, beliefs, and actions in a context of science curriculum change. Journal of Research in Science Teaching, 32(3), 225-242. https://doi.org/10.1002/tea.3660320304

Tutkun, Ö. F. (2010). The philosophic dimensions of curriculum in the 21st century. Gazi University, Journal of Gazi Educational Faculty, 30(3), 993-1016.

Tyler, R. P. (2014). Eğitim programlarının ve ögretimin temel ilkeleri [Basic principles of curriculum and instruction ] (M. E. Rüzgar \& B. Aslan, Trans.). Ankara: Pegem Akademi Yayincllk (Original work published 1949).

Wahyudi, W. (2007, September). Using metaphors to explore teachers 'perceptions of school science curriculum: an Indonesian lower secondary schools case. Paper presented at the Second International Conference on Science and Mathematics Education, Penang, Malaysia. Retrieved from http://ftp.recsam.edu.my/cosmed/cosmed07/AbstractsFullPapers2007/SCIENCE\%5CS040A.pdf 
Yanık, A. E. (2008). Primary school English teachers' perceptions of the English language curriculum of 6th, 7th and 8th grades. Hacettepe University Journal of Education, 35, 123-134.

Yeşilpınar-Uyar, M. (2016). A need analysis study regarding to develop a school-based curriculum for teaching principles and methods course. Pegem Journal of Education and Instruction, 6(1), 73-96. https://doi.org/10.14527/pegegog.2016.005

Yıldırım, A., \& Kasapoğlu, K. (2015). Teachers' perceptions of constructivist curriculum change as a predictor of their perceptions of the implementation of constructivist teaching-learning activities. Asia Pacific Education Review, 16(4), 565-577. https://doi.org/10.1007/s12564-015-9394-5

Yıldırım, A., \& Şimşek, H. (2008). Sosyal bilimlerde nitel araştırma yöntemleri [Qualitative research methods in social sciences] (7th ed.). Ankara: Seçkin Yayıncılık.

Yurdakul, B. (2015). Perceptions of elementary school teachers concerning the concept of curriculum. Educational Sciences: Theory and Practice, 15(1), 125-139. https://doi.org/10.12738/estp.2015.1.2168

\section{Note}

Note 1. This study was presented at 4th International Conference on Curriculum and Instruction (October 27-30, 2016, Antalya, Turkey).

\section{Copyrights}

Copyright for this article is retained by the author(s), with first publication rights granted to the journal.

This is an open-access article distributed under the terms and conditions of the Creative Commons Attribution license (http://creativecommons.org/licenses/by/4.0/). 